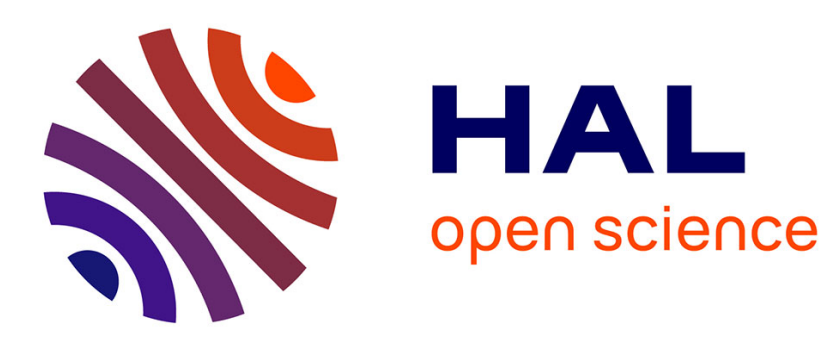

\title{
Mechanical Response and Damage of Woven Composite Materials Reinforced with Fique
}

Octavio Andrés González Estrada, German Díaz, Jabid Quiroga Mendez

\section{To cite this version:}

Octavio Andrés González Estrada, German Díaz, Jabid Quiroga Mendez. Mechanical Response and Damage of Woven Composite Materials Reinforced with Fique. Key Engineering Materials, 2018, 774, pp.143 - 148. 10.4028/www.scientific.net/KEM.774.143 . hal-01879053

\section{HAL Id: hal-01879053 https://hal.science/hal-01879053}

Submitted on 21 Sep 2018

HAL is a multi-disciplinary open access archive for the deposit and dissemination of scientific research documents, whether they are published or not. The documents may come from teaching and research institutions in France or abroad, or from public or private research centers.
L'archive ouverte pluridisciplinaire HAL, est destinée au dépôt et à la diffusion de documents scientifiques de niveau recherche, publiés ou non, émanant des établissements d'enseignement et de recherche français ou étrangers, des laboratoires publics ou privés. 


\title{
Mechanical Response and Damage of Woven Composite Materials Reinforced with Fique
}

\author{
Octavio Andrés González-Estrada1, a, German Díaz²,b \\ and Jabid Quiroga ${ }^{3, c}$ \\ ${ }^{1}$ GIC, School of Mechanical Engineering, Universidad Industrial de Santander, Ciudad \\ Universitaria, Bucaramanga, Colombia. Orcid: 0000-0002-2778-3389. \\ ${ }^{2}$ School of Industrial Design, Universidad Industrial de Santander, Ciudad Universitaria, \\ Bucaramanga, Colombia. \\ ${ }^{3}$ GIEMA, School of Mechanical Engineering, Universidad Industrial de Santander, Ciudad \\ Universitaria, Bucaramanga, Colombia. \\ aagonzale@saber.uis.edu.co, bgerman.diaz1@correo.uis.edu.co, cjabib@uis.edu.co
}

Keywords: composites, natural fibre, finite elements, woven fibres, mechanical properties.

\begin{abstract}
In this paper, we present the experimental and numerical modelling for the mechanical behaviour of woven composites reinforced with fique (furcraea selloa) fibre, for different fique fibre woven configurations embed in an R744 epoxy matrix. The woven configurations are taken from commercial models and their mechanical properties validated by experimental data. We perform experimental tests using ASTM D3039 for the tensile response. We obtain values for Young's modulus, ultimate strength, and deformation of unidirectional and woven reinforced composites. Scanning electron microscopy (SEM) is used for the fractographic analysis of the reinforced specimens. For the numerical model of the woven composite, we use the Texgen software to define the finite element voxel model and to estimate orthotropic mechanical parameters. Then, we determine the equivalent elastic properties of the composite, according to the materials and the fibrematrix relations. We compare and validate the numerical results with the experimental data. We obtain stress and strain fields for the yarns and the matrix. The objective of this work is to establish a baseline of the mechanical behaviour of these natural reinforced composites to propose applications for structural engineering.
\end{abstract}

\section{Introduction}

In recent decades, the use of natural fibres has emerged as a response to the need for sustainable composites materials. Composites reinforced with natural fibres have gained attention among the industrial an academic communities, and efforts to characterize and evaluate their mechanical behaviour have been done for several fibres, e.g., jute, sisal, fique, etc. [1]-[3], mostly for unidirectional laminates. Low environmental impact, low cost and a wide range of applications are some of their unique features [4], [5], [1], [6]. To optimize the performance of natural fibre composites, we can improve the adhesion between the fibres and the polymer matrix, or develop appropriate geometries and configurations of the reinforcement phase, which contribute to increase the mechanical properties of the composite [7]-[9].

Composites materials reinforced with woven fibres are a good alternative in many applications, and they can be found in several configurations depending on the textile used, e.g., 2D laminated textile, $2 \mathrm{D}$ braided textile, etc. In this regard, Wang et al. [10] have developed methods for woven fibres to use RVE with periodic boundary conditions for finite element analysis in micro and meso scales.

Reinforcement textiles can be recreated in different manners. Texgen software can reproduce the hierarchical structures and the geometric patterns of complex textiles [11], [12]. Numerical models using finite elements (FE) can be used to represent the mechanical response of composites with 
textiles [13]-[16]. The mesoscale modelling of textile composites is used to homogenize mechanical properties by evaluating the stress and strain fields inside a representative unit cell. The conditions for failure start and failure development, associated with damage properties of the materials, elastic properties and geometric characteristics may be proposed based on unit cells [17], [18].

In this work, we investigate the mechanical response of a polymer-matrix composite reinforced with natural fibres of fique in the form of woven textile. The configuration of the natural textile was taken from commercial models and mechanical properties were obtained by ASTM tensile tests. Numerical models to predict the elastic constants are used, both considering the general rule of mixtures and finite element models, for different fibre configurations, showing good agreement with experimental results.

\section{Materials and methods}

The classical linear elasticity problem is considered, given by the internal equilibrium equation, and Dirichlet and Neumann boundary conditions. We assume materials with linear elastic behaviour, under the generalized Hooke's law for anisotropic materials [19]. The textile architecture is modelled using the TexGen software [12], in two different configurations. We assume that both the yarn and the matrix behave as isotropic bodies.

Fique natural fibres (furcraea andina), supplied by Coohilados del Fonce Ltd., were used. The fique fibre has a density of $0,72 \mathrm{~g} / \mathrm{cm}^{3}$, for a linear density of 31,32 tex, with an average cross-section of $0,176 \mathrm{~mm}^{2}$ and a diameter of $0,473 \mathrm{~mm}$ [20]. Applying descriptive statistics, it was found that the yarn used is formed of approximately 29 fibres with an estimated diameter of $0.016 \mathrm{~mm}$ and an apparent thread diameter of $1.444 \mathrm{~mm}$. Elastic modulus for fique is $22,06 \mathrm{GPa}$ (measured with a fibre length of $250 \mathrm{~mm}$ ), shear modulus $8,82 \mathrm{GPa}$ and Poisson ratio 0,25 , with an ultimate tensile stress of $780 \mathrm{MPa}$. These values were obtained experimentally for a single thread. The epoxy resin R744 was assumed as a homogeneous isotropic material, with an elastic modulus of 0,951 MPa. One of the textiles used is shown in Fig. 1. The dimensions of the models are $250 \times 25 \times 10 \mathrm{~mm}$, the thread that forms the fabric is $1.44 \mathrm{~mm}$ in diameter.

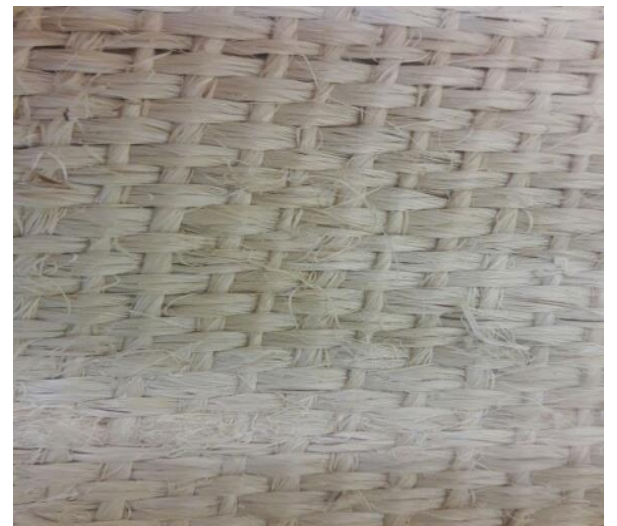

(a) Original textile.

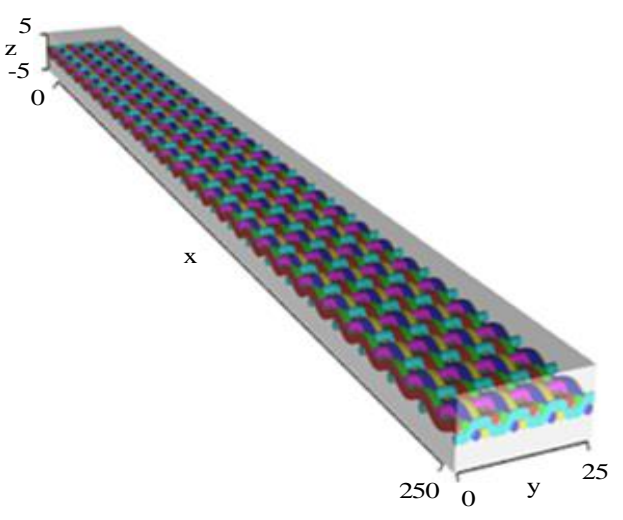

(b) Geometric model.

Figure 1 . Model of the textile $2 \times 1$.

\section{Results}

To determine the mechanical properties of the proposed composites, tensile tests were carried out on a universal MTS BIONIX testing machine with a load cell of $25 \mathrm{kN} ; 3$ types of specimens were considered, unidirectional (UD), textile 1 and textile 2. The procedure and the size of the samples were made according to ASTM D3039, the specimens are shown in Fig. 2. 
In Table 1, we show the results of the tensile tests after the corresponding data treatment for each type of specimens. Note the effect of the reinforcement on the properties of the material, even for low volume fractions. Ultimate stress, $\sigma_{\mathrm{u}}$, and Young's modulus, $\mathrm{E}_{1}$, increase with the number of threads, and the strain, $\varepsilon_{\max }$, decreases, which is consistent with the expected material response. For the samples with reinforced woven fibres, it is observed that Young's modulus and ultimate stress increase, and the strain decreases, compared with the epoxy specimen.

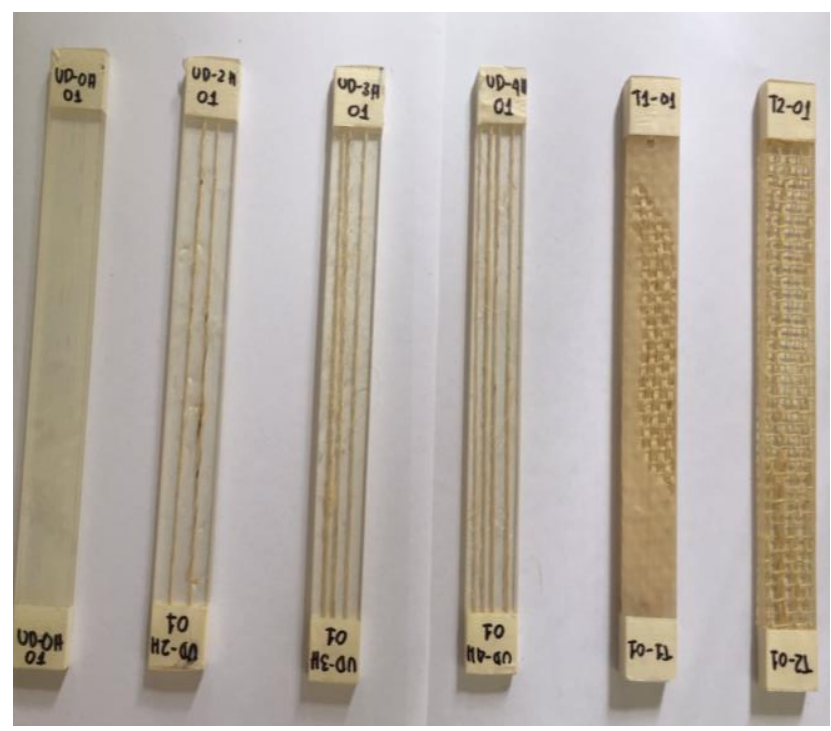

Figure 2. Specimens for the tensile tests.

Table 1. Mechanical properties from tensile tests for epoxy and composite configurations.

\begin{tabular}{llll}
\hline Specimen type & $\boldsymbol{\sigma}_{\text {u. }}[\mathbf{M P a}]$ & $\mathbf{\varepsilon m a x}[\mathbf{m m} / \mathbf{m m}]$ & $\mathbf{E}_{\mathbf{1}}[\mathbf{G P a}]$ \\
\hline Epoxy & $25,237 \pm 1,218$ & $7,470 \pm 0,316$ & $0,951 \pm 2,044$ \\
UD, 2 threads & $28,803 \pm 1,135$ & $2,975 \pm 0,022$ & $1,417 \pm 1,440$ \\
UD, 3 threads & $28,137 \pm 2,517$ & $2,617 \pm 0,126$ & $1,528 \pm 0,727$ \\
UD, 4 threads & $30,477 \pm 1,518$ & $2,783 \pm 0,015$ & $1,658 \pm 1,181$ \\
Textile 1 & $28,150 \pm 1,603$ & $2,938 \pm 1,438$ & $1,587 \pm 0,797$ \\
Textile 2 & $30,254 \pm 1,155$ & $3,420 \pm 0,285$ & $1,509 \pm 0,561$ \\
\hline
\end{tabular}

For the fractographic analysis, images were obtained by scanning electron microscopy (SEM), using a Quanta FEG 650 microscope. Note in Fig. 3 that the failure mode for the tensile tests indicates a good adhesion between the fibre and the matrix, which improves the properties of the material [2]. Impregnation of the matrix between the fibres of the threads of the textile is optimal, which indicates an appropriate process of casting and curing [21]. The fibre pull-out of the warp could be due to the lack of fibre preparation treatments, which are used to detach the layers of hemicellulose and lignin from its surface, to improve the adhesion between fibre and matrix. Also, small marks left by the weft are observed. Despite the minimal extraction, it can be observed that the material failed uniformly, little evidence of delamination is observed [22], [23].

Finite element model. A conventional Galerkin formulation is used for the finite element model of the linear elastic problem. For the topological model, a voxelized mesh was used, which was obtained using TexGen [24]. The boundary conditions are consistent with the ASTM tensile tests.

Elastic model of unidirectional and woven fibres. Initially, we obtained the elastic constants for the composite material with unidirectional fibres: orthotropic elastic moduli $\mathrm{E}_{1}, \mathrm{E}_{2}$, shear modulus $\mathrm{G}_{12}$, and Poisson coefficients $v_{12}, v_{21}$, Table 2 . 

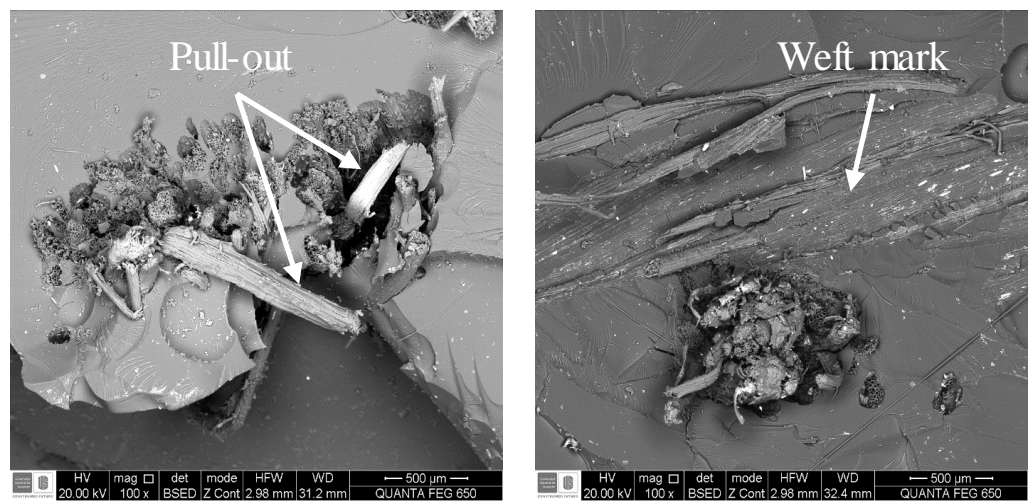

Figure 3. SEM results for the textile 1 under tensile loads.

Table 2. Elastic constants for unidirectional fibres considering a different number of threads.

\begin{tabular}{cccccc}
\hline Threads & $\mathbf{E}_{\mathbf{1}}[\mathbf{G P a}]$ & $\mathbf{E}_{\mathbf{2}}[\mathbf{G P a}]$ & $\mathbf{G}_{\mathbf{1 2}}[\mathbf{G P a}]$ & $\mathbf{v}_{\mathbf{1 2}}$ & $\mathbf{v}_{\mathbf{2 1}}$ \\
\hline 2 & 1,346 & 0,968 & 0,394 & 0,348 & 0,250 \\
3 & 1,544 & 0,977 & 0,401 & 0,347 & 0,220 \\
4 & 1,741 & 0,986 & 0,408 & 0,346 & 0,196 \\
\hline
\end{tabular}

We use the rule of mixtures to estimate the elastic modulus for the different volume fractions. Table 3 shows the error between the experimental, $\mathrm{E}_{1, \mathrm{exp}}$, and the estimated value, $\mathrm{E}_{1, \mathrm{RM}}$. Then, the elastic modulus obtained by finite elements, $\mathrm{E}_{\mathrm{FE}}$, was evaluated for each model, including the textiles. The error with respect to the values obtained experimentally is small, as shown in Table 3.

Table 3. Comparison of elastic modulus for experimental, rule of mixtures and FE models.

\begin{tabular}{cccccc}
\hline Specimen type & $\mathbf{E}_{\mathbf{1 , \boldsymbol { e x p }}}[\mathbf{G P a}]$ & $\mathbf{E}_{\mathbf{1 , \mathbf { R M }}}[\mathbf{G P a}]$ & $\mathbf{\%}$ error & $\mathbf{E}_{\mathbf{F E}}[\mathbf{G P a}]$ & \% error \\
\hline UD de 2 hilos & 1,417 & 1,346 & 5,01 & 1,376 & 2,89 \\
UD de 3 hilos & 1,527 & 1,544 & 1,11 & 1,461 & 4,36 \\
UD de 4 hilos & 1,657 & 1,741 & 5,06 & 1,629 & 1,69 \\
Tejido 1 & 1,587 & N/A & N/A & 1,693 & 6,67 \\
Tejido 2 & 1,509 & N/A & N/A & 1,457 & 3,44 \\
\hline
\end{tabular}

With the voxelized FE model, a load of $8000 \mathrm{~N}$ was applied to obtain the stress distribution for each material. Fig. 4 shows the von Mises stress distribution for textile 1, displaying the reinforcement fabric and the epoxy matrix. As expected, the warp of the textile exhibits the highest stress, close to $500 \mathrm{MPa}$, while the transverse threads, weft, show compression stress close to the intersection with the warp. For the epoxy, the stress is high in the spaces between the longitudinal threads, which could cause separation of the matrix from the transverse threads. Considering that the cross-section of the model has an area of $250 \mathrm{~mm}^{2}$, the nominal stress is $32 \mathrm{MPa}$. Thus, the composite fails because the stress on the matrix exceeds the ultimate stress.

\section{Conclusions}

Tensile tests were done according to ASTM D3039 for different composite configurations. Epoxy R744 was reinforced with woven fique fibres and an increase in Young's modulus up to $66.8 \%$ was evidenced. Using voxel FE models, we could approximate the stress distributions for the textile and matrix. Longitudinal fibres show higher values of stress, as expected. The intersection with transverse fibres shows high stress values for the epoxy. According to FE results, the failure mechanism might be associated with the areas where the matrix exceeds the allowable stress. 

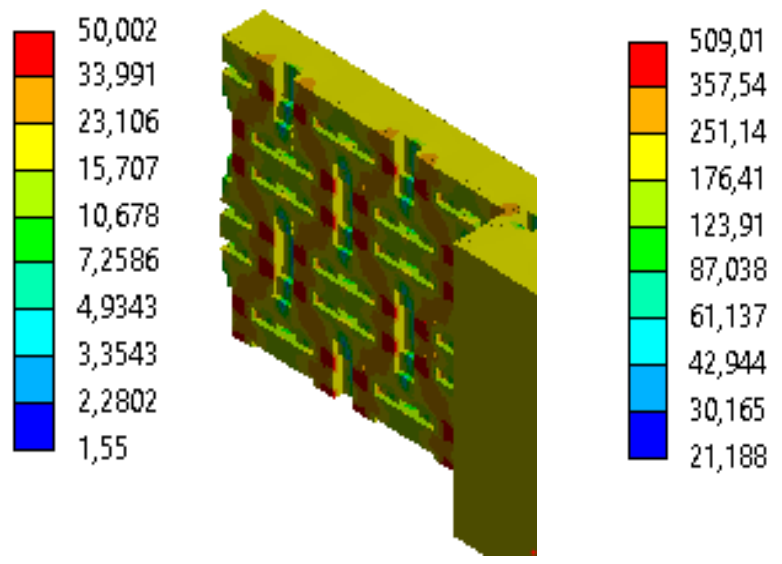

(a) Epoxy

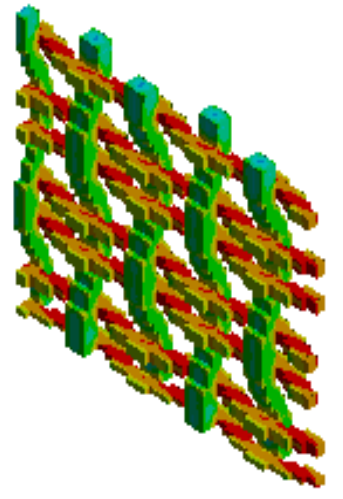

(b) Textile 1

Figure 4. Von Mises stress for the composite with textile 1.

Numerical results using FE models presented differences below $6.8 \%$ with respect to the data obtained experimentally, for the elastic constants of the material. This indicates that the model has good agreement with experimental values, and could be used to study other composite configurations and volume fractions.

\section{Acknowledgements}

We acknowledge the collaboration of the Laboratory of Microscopy and Laboratory of Mechanical Testing, Universidad Industrial de Santander.

\section{References}

[1] K. L. Pickering, M. G. G. A. Efendy, and T. M. Le, "A review of recent developments in natural fibre composites and their mechanical performance," Composites Part A: Applied Science and Manufacturing, vol. 83. pp. 98-112, Apr-2016.

[2] M. F. Contreras, W. A. Hormaza, and A. Marañón, "Fractografía De La Fibra Natural Extraida Del Fique Y De Un Material Compuesto Reforzado Con Tejido De Fibra," Rev. Latinoam. Metal. y Mater., vol. 1, no. 1, pp. 57-67, 2009.

[3] S. Gómez, B. B. Ramón, and R. Guzman, "Comparative study of the mechanical and vibratory properties of a composite reinforced with fique fibers versus a composite with E-glass fibers," Rev. UIS Ing., vol. 17, no. 1, pp. 43-50, 2018.

[4] M. A. Hidalgo-Salazar, M. F. Muñoz, and J. H. Mina, "Influence of Incorporation of Natural Fibers on the Physical, Mechanical, and Thermal Properties of Composites LDPE-Al Reinforced with Fique Fibers," Int. J. Polym. Sci., vol. 2015, no. 386325, pp. 1-8, 2015.

[5] J. C. Posada-correa, L. Y. Jaramillo-zapata, P. A. Villegas-bolaños, L. A. García, and C. A. Vargas-isaza, "Estudio comparativo de negro de humo y alúmina como cargas reforzantes en mezclas de caucho natural," Rev. UIS Ing., vol. 13, no. 2, pp. 59-67, 2014.

[6] L. Yan, B. Kasal, and L. Huang, "A review of recent research on the use of cellulosic fibres, their fibre fabric reinforced cementitious, geo-polymer and polymer composites in civil engineering," Composites Part B: Engineering, vol. 92. pp. 94-132, 2016.

[7] Y. Zhou, M. Fan, and L. Chen, "Interface and bonding mechanisms of plant fibre composites: An overview," Compos. Part B Eng., vol. 101, pp. 31-45, Sep. 2016.

[8] E. Omrani, P. L. Menezes, and P. K. Rohatgi, "State of the art on tribological behavior of polymer matrix composites reinforced with natural fibers in the green materials world," Eng. Sci. Technol. an Int. J., vol. 19, no. 2, pp. 717-736, Jun. 2016. 
[9] F. P. La Mantia and M. Morreale, "Green composites: A brief review," Compos. Part A Appl. Sci. Manuf., vol. 42, no. 6, pp. 579-588, 2011.

[10] X. F. Wang, X. W. Wang, G. M. Zhou, and C. W. Zhou, "Multi-scale Analyses of 3D Woven Composite Based On Periodicity Boundary Conditions," J. Compos. Mater., vol. 41, no. 14, pp. 1773-1788, 2007.

[11] H. Lin, L. P. Brown, and A. C. Long, "Modelling and Simulating Textile Structures Using TexGen," Adv. Mater. Res., vol. 331, pp. 44-47, 2011.

[12] M. Sherburn, "Geometric and Mechanical Modelling of Textiles," University of Nottingham, 2007.

[13] S. Dai and P. R. Cunningham, "Multi-scale damage modelling of 3D woven composites under uni-axial tension,” Compos. Struct., vol. 142, pp. 298-312, May 2016.

[14] A. Dixit, H. S. Mali, and R. K. Misra, "Unit cell model of woven fabric textile composite for multiscale analysis," in Procedia Engineering, 2013, vol. 68, pp. 352-358.

[15] H. Lin, M. Sherburn, J. Crookston, A. C. Long, M. J. Clifford, and I. A. Jones, "Finite element modelling of fabric compression," Model. Simul. Mater. Sci. Eng., vol. 16, no. 3, p. 35010, Jan. 2008.

[16] O. A. González-Estrada, J. Leal Enciso, and J. D. Reyes Herrera, "Análisis de integridad estructural de tuberías de material compuesto para el transporte de hidrocarburos por elementos finitos," Rev. UIS Ing., vol. 15, no. 2, pp. 105-116, Jan. 2016.

[17] S. V. Lomov et al., "Textile composites: Modelling strategies," Compos. - Part A Appl. Sci. Manuf., vol. 32, no. 10, pp. 1379-1394, 2001.

[18] S. V Lomov, E. Bernal, D. S. Ivanov, S. V Kondratiev, and I. Verpoest, "Homogenisation of a sheared unit cell of textile composites," Rev. Eur. des Éléments Finis, vol. 14, no. 6-7, pp. 709-728, 2005.

[19] M. Ansar, W. Xinwei, and Z. Chouwei, "Modeling strategies of 3D woven composites: A review," Compos. Struct., vol. 93, no. 8, pp. 1947-1963, 2011.

[20] M. A. Camargo Mendez and D. F. Garcia Alfonzo, "Material compuesto de matriz polimerica reforzado con fibras naturales para la fabricacion de tenso-estructuras," Universidad industrial de Santander, 2017.

[21] C. Lozano Tafur, "Deformación y fractura de una resina epóxica reforzada con fibra de algodón," Universidad Nacional de Colombia, Bogota, Colombia, 2016.

[22] S. N. Monteiro, F. P. D. Lopes, A. P. Barbosa, A. B. Bevitori, I. L. Amaral Da Silva, and L. L. Da Costa, "Natural lignocellulosic fibers as engineering materials-An overview," Metall. Mater. Trans. A Phys. Metall. Mater. Sci., vol. 42, no. 10, pp. 2963-2974, 2011.

[23] M. Hughes, J. Carpenter, and C. Hill, "Deformation and fracture behaviour of flax fibre reinforced thermosetting polymer matrix composites," J. Mater. Sci., vol. 42, no. 7, pp. 24992511, Mar. 2007.

[24] A. Doitrand, C. Fagiano, V. Chiaruttini, F. H. Leroy, A. Mavel, and M. Hirsekorn, "Experimental characterization and numerical modeling of damage at the mesoscopic scale of woven polymer matrix composites under quasi-static tensile loading," Compos. Sci. Technol., vol. 119, pp. 1-11, Nov. 2015. 